\title{
Inventory of aspen trees in spruce dominated stands in conservation area
}

\author{
Matti Maltamo ${ }^{1 *}$, Annukka Pesonen ${ }^{2}$, Lauri Korhonen ${ }^{1}$, Jari Kouki ${ }^{1}$, Mikko Vehmas ${ }^{3}$ and Kalle Eerikäinen ${ }^{4}$
}

\begin{abstract}
Background: The occurrence of aspen trees increases the conservation value of mature conifer dominated forests. Aspens typically occur as scattered individuals among major tree species, and therefore the inventory of aspens is challenging.

Methods: We characterized aspen populations in a boreal nature reserve using diameter distribution, spatial pattern, and forest attributes: volume, number of aspens, number of large aspen stems and basal area median diameter. The data were collected from three separate forest stands in Koli National Park, eastern Finland. At each site, we measured breast height diameter and coordinates of each aspen. The comparison of inventory methods of aspens within the three stands was based on simulations with mapped field data. We mimicked stand level inventory by locating varying numbers of fixed area circular plots both systematically and randomly within the stands. Additionally, we also tested if the use of airborne laser scanning (ALS) data as auxiliary information would improve the accuracy of the stand level inventory by applying the probability proportional to size sampling to assist the selection of field plot locations.
\end{abstract}

Results: The results showed that aspens were always clustered, and the diameter distributions indicated different stand structures in the three investigated forest stands. The reliability of the volume and number of large aspen trees varied from relative root mean square error figures above $50 \%$ with fewer sample plots (5-10) to values of $25 \%-50 \%$ with 10 or more sample plots. Stand level inventory estimates were also able to detect spatial pattern and the shape of the diameter distribution. In addition, ALS-based auxiliary information could be useful in guiding the inventories, but caution should be used when applying the ALS-supported inventory technique.

Conclusions: This study characterized European aspen populations for the purposes of monitoring and management of boreal conservation areas. Our results suggest that if the number of sample plots is adequate, i.e. 10 or more stand level inventory will provide accurate enough forest attributes estimates in conservation areas (minimum accuracy requirement of RMSE\% is 20\%-50\%). Even for the more ecologically valuable attributes, such as diameter distribution, spatial pattern and large aspens, the estimates are acceptable for conservation purposes.

Keywords: Diameter distribution; Historical continuity; Inventory; LiDAR; Populus tremula L; Simulation; Spatial arrangement; Stand characteristics

\section{Background}

One of the most interesting minor tree species in boreal forests of northern Europe is the European aspen (Populus tremula L.). The importance of aspen is closely related to its biodiversity values because it hosts particularly diverse groups of associated species, many of which are threatened in Fennoscandia (Esseen et al. 1992; Kouki et al.

\footnotetext{
*Correspondence: matti.maltamo@uef.fi

'University of Eastern Finland, School of Forest Science, P.O. Box 111, FI-80101 Joensuu, Finland

Full list of author information is available at the end of the article
}

2004). In addition, large-sized aspens have generally disappeared from managed forests because they have low economic value and are intermediate hosts of the pine rust fungus (Melampsora pinitorqua [Braun] Rostr.) that causes serious damage to young pine stands (Kurkela 1973; Heliövaara and Väisänen 1984).

Although aspen is a typical species in post-disturbance, early successional stages, recent studies have indicated that aspen can maintain its populations in natural oldgrowth coniferous forests for up to several hundred years,

\section{它 Springer}


even though they may slowly decline in abundance (Lilja et al. 2006; Vehmas et al. 2009b). In particular, old and large-sized aspen trees, which are most valuable for biodiversity, are mostly found in mature and old-growth mixed forests where they grow in small groups or as scattered individuals (Tikka 1954; Syrjänen et al. 1994). Because the spatiotemporal continuity of ecologically important characteristics is regarded as important for conservation purposes (Stokland et al. 2002; Kouki et al. 2004) the ability to inventory and monitor aspen trees is essential for the management of conservation areas.

Several variables can be used to describe aspens in stand-level forest inventories. First, the existence of aspen can be recorded. Secondly, detail on the amount and size of aspen trees is of interest; in stand-level inventories, they are usually described using basal area, mean diameter, and mean height (Koivuniemi and Korhonen 2006). Thirdly, from a biodiversity point of a view, information on size variation and spatial distribution is highly relevant (Kouki et al. 2004). The determination of spatial distribution requires that the trees are individually mapped, which is usually practically impossible to conduct in field surveys, except for research purposes. Correspondingly, the tree height distributions are usually not assessed due to the laborious field measurements, whereas diameter distributions can be obtained. With this information, some indicators of the naturalness of the forest structure, such as the shape of the diameter distribution, of the given aspen population can be assessed. Furthermore, it is easy to define the proportion of large aspens when their diameters at breast height $(d b h)$ are, for instance, greater than $25 \mathrm{~cm}$.

The problem related to the assessment of aspen at stand-level inventories is that the low density of the aspen trees results in high estimates of sampling errors. It is also possible that aspens are not separated from other economically less-important deciduous species in tree stock descriptions for forest management. In validation studies of the inventories by compartments, the root mean square errors (RMSEs) obtained for the total growing stock volume have ranged from $15 \%-38 \%$ (Poso 1983; Haara and Korhonen 2004). However, speciesspecific errors are considerably higher, being 29\%, $43 \%$ and 65\% for Scots pine (Pinus sylvestris L.), Norway spruce (Picea abies L.), and the group consisting of silver birch (Betula pendula Roth) and downy birch (B. pubescens Ehrh), respectively (Haara and Korhonen 2004). While the errors are usually acceptable for the dominant coniferous species, minor deciduous tree species are described too inaccurately for many purposes. For European aspen, the relative RMSE can be several hundreds of percent (Arto Haara, personal comm.).

Airborne laser scanning (ALS) -based technology has been successfully applied to stand-level inventories during recent years (Næsset 2007; Maltamo and Packalen 2014). Forest characteristics are usually estimated with 100\% coverage for the inventory area by utilising the area-based approach (ABA), i.e. statistical relationships between forest attributes and ALS metrics at the plot level. The first applications estimated forest characteristics as a whole, but the inventory system by Packalén and Maltamo (2007), which also utilizes aerial photographs and relies on non-parametric imputation, was the first species-specific estimator for forest attributes. However, deciduous tree species are usually pooled into one single group (Packalén and Maltamo 2007). Thus, the previously developed ALS based inventory approaches are not appropriate for providing species-specific information on aspen. In studies by Breidenbach et al. (2010) and Pippuri et al. (2013) speciesspecific ALS inventory has also been applied to identify aspens, but the RMSE values have been over $100 \%$.

ALS can also provide information about individual trees, which can be aggregated to the stand level. In a study by Säynäjoki et al. (2008), single aspen trees were detected from dense ALS data. The inventory system was, however, rather complex, including, for instance, visual interpretations by aerial images to separate coniferous trees from deciduous trees. As a result, the classification accuracy of large $(d b h>25 \mathrm{~cm})$ aspen trees was $78.6 \%$. In addition, discrimination of aspen can be difficult because the ALS intensity metrics that are important in species detection overlap with spruce and birch (Ørka HO et al. 2007; Korpela et al. 2010).

Despite the recent advances in tree-level identification, it is challenging to obtain stand-level information on aspen in remote sensing-based forest inventories. Correspondingly, the accuracy estimates have been rather low for aspen, or it has been completely ignored in traditional field inventories. Since the trend in forest inventories is toward remote sensing applications, rare and scattered tree species, such as aspen, could become neglected in inventories. On the other hand, there is an increasing need to have forest inventory information on aspen, especially in conservation areas where the occurrence and long-term persistence of scattered aspen trees may be crucial for many conservationdependent species.

The goal of this study was to characterise aspen populations in a boreal nature reserve. The study data are based on mapped individual aspens in three separate spruce dominated forest stands. In this unique data set the aspen populations have developed without the effects of active forest silviculture during recent decades. We characterised aspen using diameter distribution, spatial pattern of trees and forest attributes volume $\left(V, \mathrm{~m}^{3} \cdot \mathrm{ha}^{-1}\right)$, number of stems $\left(N, \mathrm{ha}^{-1}\right)$, number of stems of large aspens $\left(N_{d b h}>25 \mathrm{~cm}, \mathrm{ha}^{-1}\right)$ and basal area median diameter $\left(D_{g} M, \mathrm{~cm}\right)$. Furthermore, we applied stand level 
inventory simulations to examine the accuracy of the estimates of these characteristics. Finally, probability proportional to size (PPS) sampling using ALS metrics as auxiliary information was evaluated as a method to improve inventory estimates.

\section{Methods}

\section{Study area and field measurements}

The study area was located in Koli National Park (NP) in eastern Finland $\left(29^{\circ} 50^{\prime} \mathrm{E}, 63^{\circ} 5^{\prime} \mathrm{N}\right)$. The area is characterised as a highly variable boreal landscape, where the altitude varies from 94-347 m above sea level (Lyytikäinen 1991; Kärkkäinen 1994). The area lies in the transitional area between the southern and middle boreal vegetation zones (Kalliola 1973). Most forests in the area are dominated by Norway spruce (Picea abies L. Karst.) and Scots pine (Pinus sylvestris L.) with a highly variable admixture of silver birch, downy birch, European aspen, and grey alder (Alnus incana [L.] Moench) (Lyytikäinen 1991; Grönlund and Hakalisto 1998).

In a study by Vehmas et al. (2009b), the historical continuity of aspen was studied based on inventory registers, and some areas where large aspens have survived from 1910 were found within the current Koli NP. Three of the largest of these stands were selected for this study (Figures 1 and 2). Other stands were very small sized, included only a few aspens or had highly irregular shape. The total area of forest stand 1 was 8.05 ha, whereas stands 2 and 3 covered 5.96 and 12.93 ha of forest, respectively (Table 1 ). Within the three stands, both $d b h$ and GPS position were recorded for all living aspen trees having a $d b h$ larger than $5 \mathrm{~cm}$ in 2006. Stem volumes of

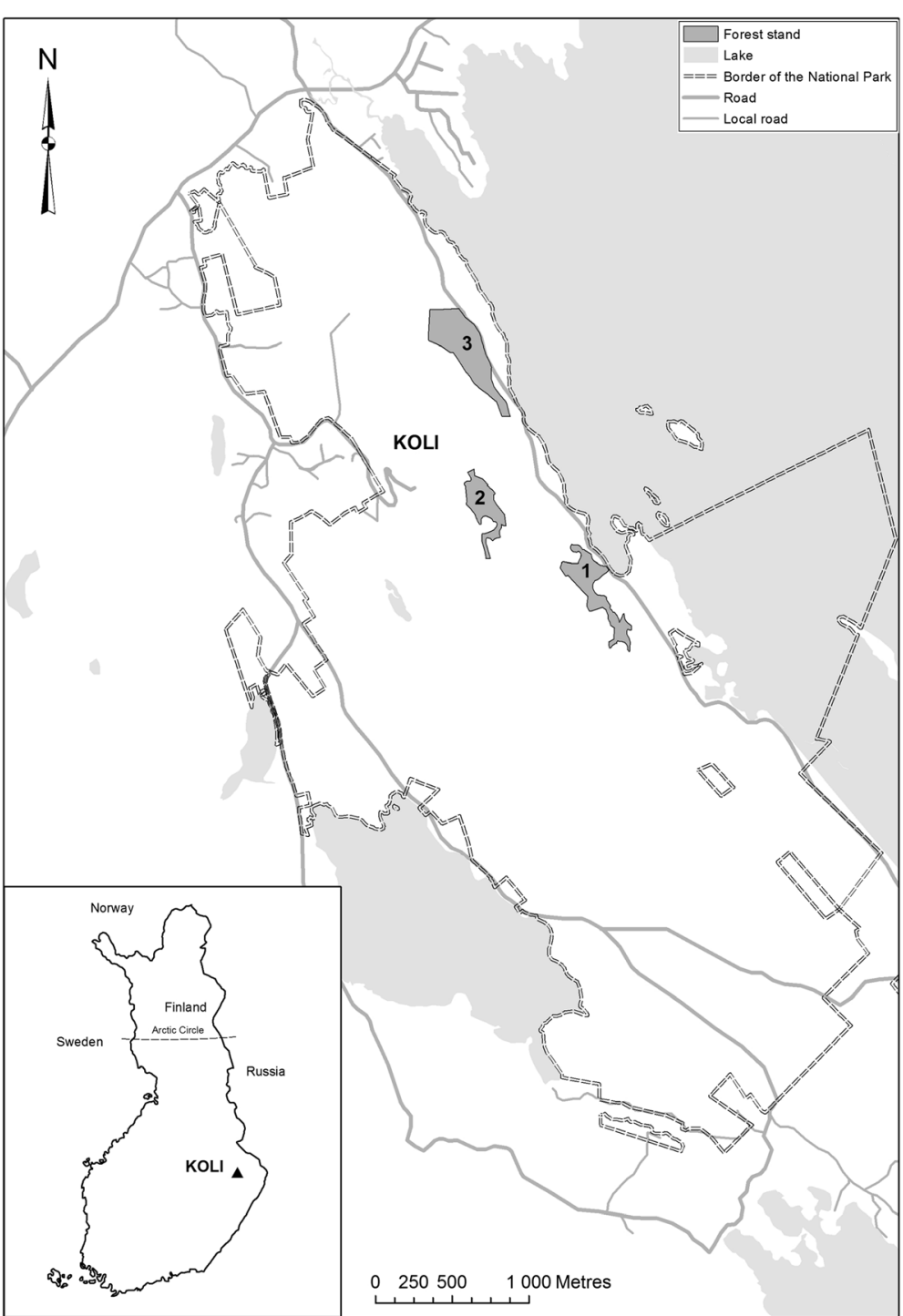

Figure 1 The location of the study area. 


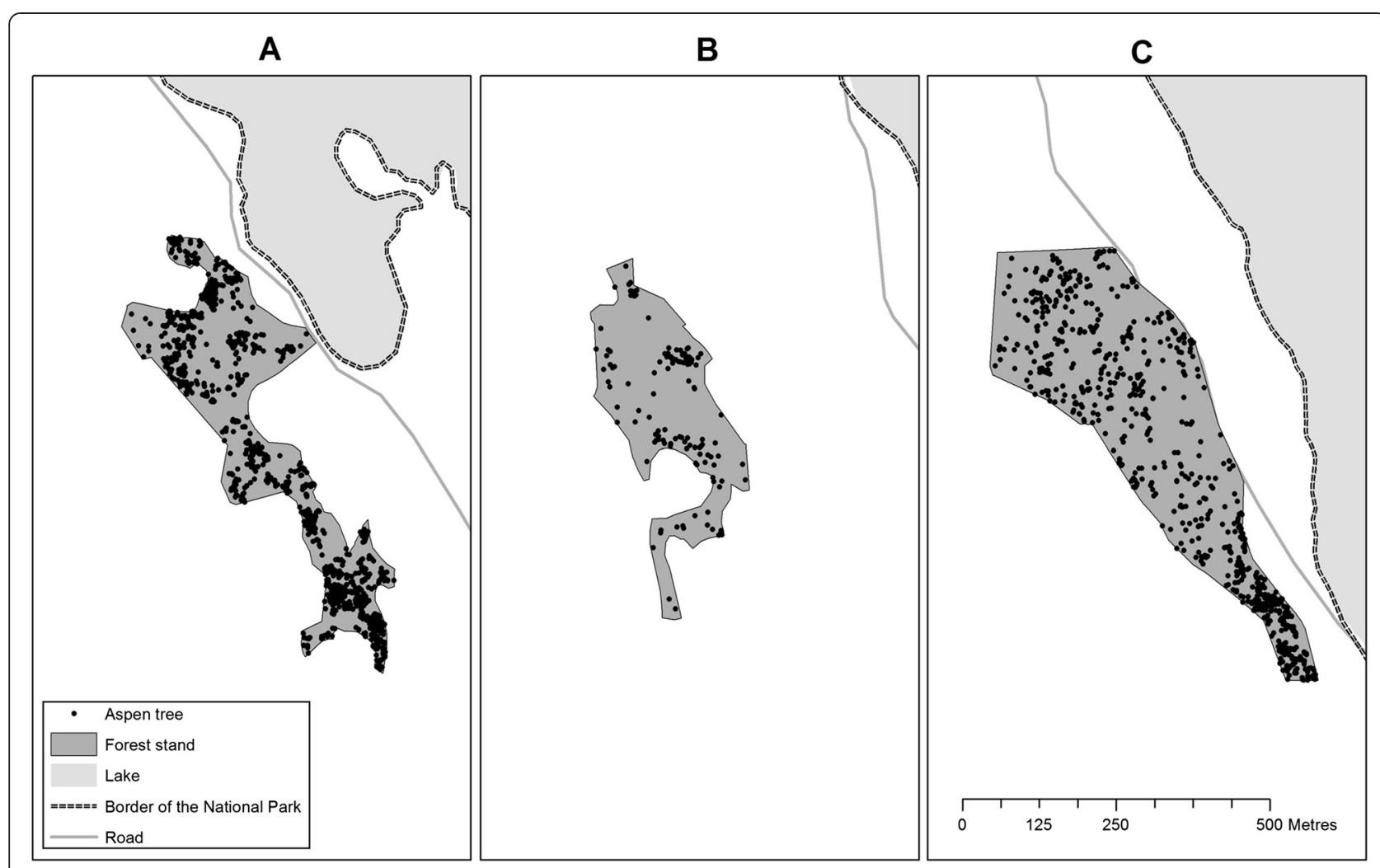

Figure 2 The study stands $(\mathbf{A}=$ stand 1, $\mathbf{B}=$ stand 2, C =stand 3$)$ with aspen tree locations.

the tallied aspens were calculated using Laasasenaho's (1982) volume function for Scots pine, since published equations were not available for European aspen (Kinnunen et al. 2007). The choice of volume model was based on expert opinion. Sum characteristics were converted to per-hectare levels, and $D_{g} M$ was calculated for the three stands (Table 1). In addition, total stand volume and

Table 1 Areas and forest attributes for European aspen and stand totals for the three study stands

\begin{tabular}{llll}
\hline Attribute & \multicolumn{2}{l}{ Stand } & $\mathbf{3}$ \\
\cline { 2 - 4 } & $\mathbf{1}$ & $\mathbf{2}$ & $\mathbf{3} .96$ \\
\hline Area $(\mathrm{ha})$ & 8.05 & 39.1 & 12.94 \\
$D_{g} M(\mathrm{~cm})$ & 22.4 & 1.9 & 49.7 \\
$G\left(\mathrm{~m}^{2} \cdot \mathrm{ha}^{-1}\right)$ & 3.8 & 12.4 & 6.0 \\
$V\left(\mathrm{~m}^{3} \cdot \mathrm{ha}^{-1}\right)$ & 22.2 & 21.3 & 35.7 \\
$N\left(\mathrm{ha}^{-1}\right)$ & 148.6 & 15.3 & 54.1 \\
$N_{\text {dbh }}>25 \mathrm{~cm}^{2}\left(\mathrm{ha}^{-1}\right)$ & 16.0 & 34.3 & 32.9 \\
$G_{\text {total }}\left(\mathrm{m}^{2} \cdot \mathrm{ha}^{-1}\right)$ & 23.2 & 363.1 & 36.8 \\
$V_{\text {total }}\left(\mathrm{m}^{3} \cdot \mathrm{ha}^{-1}\right)$ & 168.9 & 422.2
\end{tabular}

Area denotes the size of the stand, $D_{g} M, \mathrm{~cm}$ denotes basal area median diameter of aspen, $G, \mathrm{~m}^{2} \cdot h a^{-1}$ denotes basal area of aspen, $V, \mathrm{~m}^{3} \cdot \mathrm{ha}^{-1}$ denotes volume of aspen, $N, \mathrm{ha}^{-1}$ denotes number of stems of aspen, $N_{d b h>25 \mathrm{~cm} \mathrm{ha}}{ }^{-1}$ denotes number of stems of large aspens, $G_{\text {total, }} \mathrm{m}^{2} \cdot \mathrm{ha}^{-1}$ denotes basal area of the total growing stock and $V_{\text {total }} \mathrm{m}^{3} \cdot \mathrm{ha}^{-1}$ denotes volume of the total growing stock. basal area were taken from the existing stand register data and updated into aspen measurement date (see Vehmas et al. 2009b).

Additionally, 15 rectangular sample plots located in Koli NP that did not overlap with the three stands previously described were used to find the best-correlating ALS metric with aspen volume. These data were used in PPS sampling. These plots were originally established to examine single-tree detection of aspen from remote sensing data and included at least one aspen tree (Säynäjoki et al. 2008). The $d b h$ was measured and stem volumes calculated for all trees. More detailed information of the data obtained from the 15 sample plots can be found in Säynäjoki et al. (2008).

\section{Laser data}

The geo-referenced ALS point cloud data from Koli NP were collected on 13 July 2005 using an Optech ALTM 3100 scanner operating at a mean altitude of $900 \mathrm{~m}$ above ground level (a.g.l), which resulted in a nominal sampling density of ca. 4 measurements $\mathrm{m}^{-2}$. Both the first and last pulse data were recorded, and the last pulse data were employed to generate a digital terrain model (DTM) by the method explained in Axelsson (2000) using a grid cell size of $1 \mathrm{~m}$. Above ground heights (i.e., canopy heights) for the laser points were obtained by 
subtracting the DTM at the corresponding location. In this study, the pulse data obtained with the ALS sensor was reclassified to "first echo" or "last echo". It is worth noting here that the original single echoes were duplicated to both first and last echo classes, whereas the intermediate echoes were completely ignored. For more details on the original ALS data, see Vehmas et al. (2009a).

The height distribution of the first and last pulse canopy height hits was used to calculate plot-wise percentiles for $0,1,5,10,20, \ldots, 90,95,99$, and $100 \%$ heights $\left(h_{0}, h_{1}, \ldots, h_{100}\right)$ (Næsset 2004), and cumulative proportional crown densities $\left(p_{0}, p_{1}, \ldots, p_{100}\right)$ were calculated for the respective quantiles. The height distributions contained only those laser points that were classified as above-ground hits; a threshold value of $0.1 \mathrm{~m}$ was used. The $h_{5}$, for example, denotes the height at which the accumulation of laser hit heights in the vegetation was $5 \%$, and, correspondingly, $p_{5}$ denotes the proportion of laser hits that accumulated at the 5\% height. In addition, the following variables were calculated by sample plots: the laser pulse intensities accumulating in percentiles $\left(i_{10}\right.$, $\left.i_{30}, \ldots, i_{90}\right)$, the average intensity value of above-ground hits, the proportion of ground hits versus canopy hits using a threshold value of $0.1 \mathrm{~m}(\mathrm{veg})$, and the average height $\left(h_{\text {mean }}\right)$ and standard deviation of the aboveground hits $\left(h_{\mathrm{sd}}\right)$. The intensity values were used as outputted by the sensor without calibration. All metrics were calculated separately for the first and the last pulse data.

\section{Stand level inventory}

The methods for aspen inventory were studied based on simulations using field data from the three stands where all aspens were mapped. We simulated stand level inventory by placing circular plots of size $400 \mathrm{~m}^{2}$ (radius $11.28 \mathrm{~m}$ ) into the stands both systematically and randomly. The size of the plot was chosen to correspond to the grid cell size in PPS sampling (see methodology below). Five, ten, fifteen, or twenty plots were located in each study stand for different sampling intensities. All sampling alternatives were repeated 2500 times. In the simulations, plots were only included if the centre point of the plot was within the study stand. For plots located at the edge of the stand, an edge correction was applied by multiplying the attribute value of an edge plot by its expansion factor (Beers 1966):

$$
\text { Attribute }=\text { Attribute }_{\text {Edge plot }} \times \frac{\text { Plot size }}{\text { Edge plot size }}
$$

where, attribute is attribute value after correction, attribute $_{\text {Edge plot }}$ is attribute value of the edge plot, plot size is size of the sample plot, i.e., $400 \mathrm{~m}^{2}$, and edge plot size is the size of the edge plot within the stand.

This correction was made for sum attributes $V, N$, and $N_{d b h>25 \mathrm{~cm}}$ but not for $D_{g} M$. This edge correction is slightly biased but leads to considerably more accurate results than without applying any correction (Schreuder et al. 1993). Finally, the estimates of forest attributes were calculated as sample means for each sample.

Furthermore, we also tested if the use of ALS data as auxiliary information would improve the accuracy of the stand level inventory by applying PPS sampling. The basic idea of this approach is to use the ALS metric to guide the selection of field plot locations (Pesonen et al. 2010a, b). We applied the same number of sample plots as in the case of systematic and random sampling, but sampling probabilities varied according to ALS information. This was done to choose the most promising plot locations for aspen plots. First, probability layers were produced, i.e., the auxiliary data values were directly calculated for the whole stand that was divided into a grid of $20 \mathrm{~m} \times 20 \mathrm{~m}$ sample units. When applying PPS sampling, the sample units were square and are referred to as grid cells. ALS based auxiliary data values were calculated for each sample unit $\left(i=1, \ldots, N_{\text {grid }}\right.$, where $N_{\text {grid }}$ is the total number of sample units in a stand), and the probabilities of each unit $i$ being selected were determined. The selection probabilities for the sample units $\left(p_{i}\right)$ were calculated by dividing the auxiliary data value $x_{i}$ for the sample unit $i$ by the sum of the auxiliary data values over the whole area of the probability layer $\left(p_{i}=x_{\mathrm{i}} / \sum x_{i}\right)$. These selection probabilities were finally utilised in sampling $5,10,15$ or 20 sample units. The calculations were repeated 2500 times.

\section{Shape of the diameter distribution}

In stands 1 and 3 the shape of the diameter distribution estimated using the simulated fixed-radius, plot-based inventory approach was compared with the actual empirical distribution according to the developed rules. The unimodal form of diameter distribution (stand 2) was not considered. In the comparison of measured and estimated diameter distributions, the goal was to examine if the sampled distributions followed the underlying actual size distribution of aspen. The sampled diameter distributions were determined in 5- (bimodal stand) or 10-cm (descending stand) diameter classes within the range from $10-95 \mathrm{~cm}$ (See Figure 3 for actual distributions). For descending diameter distributions, the following rule was applied:

Number of stems in $10-20-\mathrm{cm}$ dbh class $>$ number of stems in $20-30-\mathrm{cm} d b h$ class $>$ number of stems in $30-40-\mathrm{cm} d b h$ class.

If this rule was fulfilled by the estimate, it was classified as a realistic estimate for the underlying empirical 

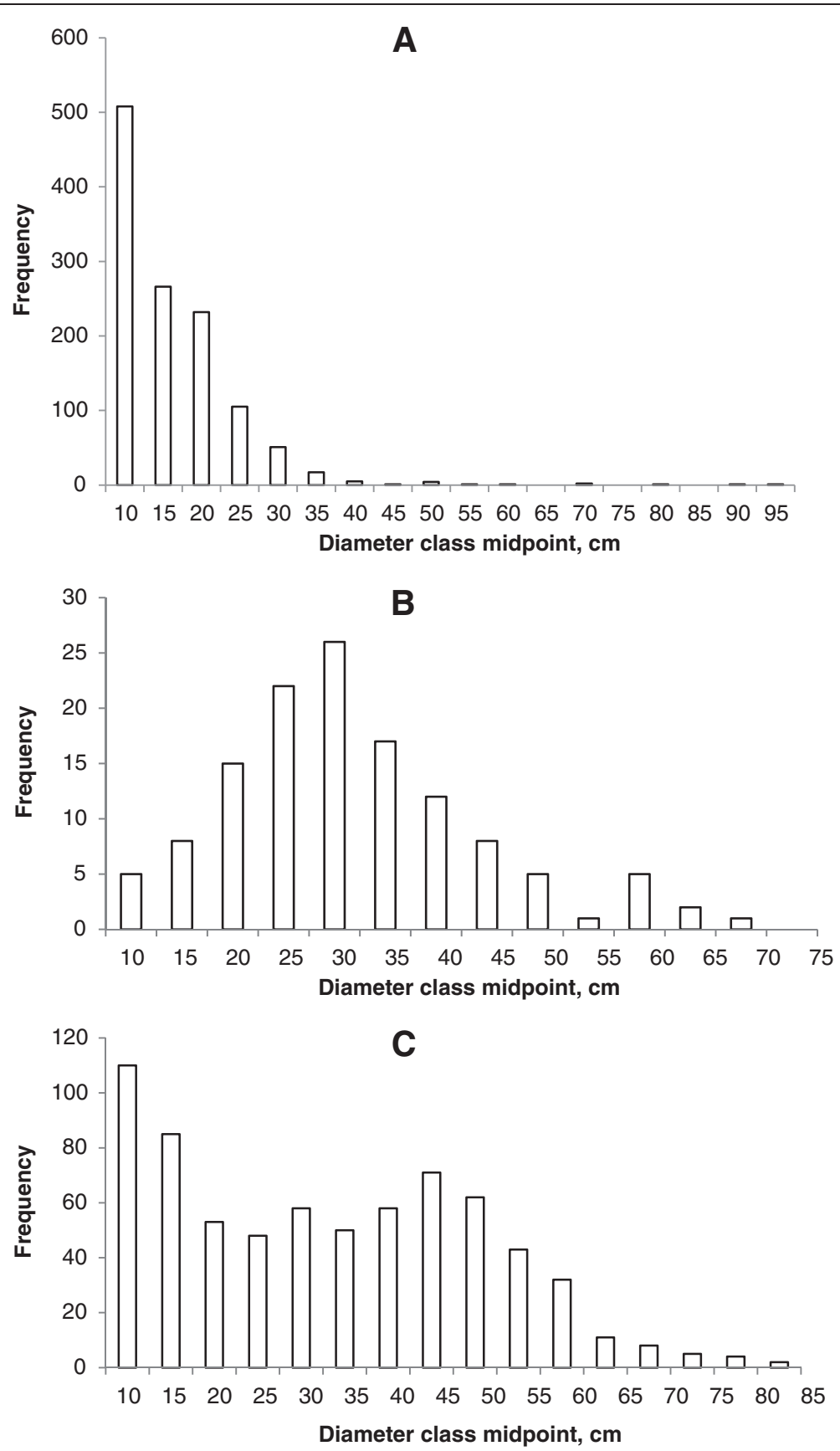

Figure 3 Diameter distribution of stands $1-3(\mathbf{A}=\operatorname{stand} 1, \mathbf{B}=$ stand $2, \mathbf{C}=$ stand 3$)$.

distribution. Correspondingly, in the case of bimodal distribution, the following rule was applied:

The first mode in the distribution is within $d b h$ classes from $10-20 \mathrm{~cm}$, and the second mode in the distribution is after the $25-30-\mathrm{cm} d b h$ class.

\section{Spatial pattern of aspens}

The spatial pattern of the aspens within the three study stands was determined by applying Ripley's K(t) function (Ripley 1981). It describes the expected number of trees at distance $t$ from a randomly selected tree. If the value of the function is larger than what would be expected based on random spacing, the spatial pattern is clustered; if smaller, it is systematic. We applied the library spatstat (Baddeley and Turner 2005) in statistical software $R$ to calculate the $K(t)$ values for each of the three stands. Isotropic correction was applied to minimize edge effects in the calculation (Ripley 1988).

The spatial patterns derived for the entire stands were compared with estimates obtained from the simulated 
samples. Therefore, a Fisher index $(I)$ was calculated for each stand-wise simulation obtained using the following equation:

$$
I=\frac{s_{n}^{2}}{\bar{n}},
$$

where $s_{n}^{2}$ is the variance of the plot-wise numbers of aspens in the sample of 20 plots and $\bar{n}$ is the mean of the plot-wise numbers of aspens. The $I$ values greater than 1 indicate clustered spatial patterns.

\section{Reliability characteristics}

The simulation results were validated in term of relative RMSE.

$$
\text { RMSE } \%=\frac{100 x \sqrt{\frac{\sum_{i=1}^{N}\left(y-\frac{\sum_{i=1}^{n} \hat{y}_{i}}{n}\right)^{2}}{N}}}{y}
$$

and bias

$$
\text { bias } \%=\frac{100 x \frac{\sum_{i=1}^{N}\left(y-\frac{\sum_{i=1}^{n} \widehat{y}_{i}}{n}\right)}{N}}{y}
$$

where $N$ is the number of simulations, $y$ is the observed value for the stand, $\hat{y}_{i}$ is the predicted value for sample plot simulation $i$, and $n$ is number of sample plots in one sample.

Finally, in the case of the ALS-guided inventory, the relative improvement in volume estimate compared to selecting sample units of $20 \mathrm{~m} \times 20 \mathrm{~m}$ with equal probabilities was calculated.

\section{Results}

\section{Reliability figures for attributes of simulated stand level} inventories

In general, the results are more accurate by means of RMSE\% when the number of sample plots increases (Table 2). An exception is stand 3 with systematic placement of plots where accuracy decreased in the case of 20 plots. This is related to the shape of the stand and, thus, to the decreased possibilities to locate the systematic sample plot network to the narrow, densely stocked southern part of the stand in simulations. In general, the results are also slightly more accurate for systematic than random plot locations especially in the case of stands
1 and 2 . The biases are in most cases below $2 \%$ and there are only a few cases where the values are over $5 \%$.

In the case of RMSE\% of $V$, which is usually regarded as the most important stand attribute, the figures are rather high with smaller number of sample plots and still remain approximately at the level of $25 \%-40 \%$ even with 20 sample plots (Table 2). In stand 2 the RMSE\% values were larger for $V$ and also for $N$ compared to stands 1 and 3. This outcome may be related to the smaller quantities of aspen in stand 2 (see Table 1). From the ecological point of a view, $N_{d b h>25 \mathrm{~cm}}$ is the most important forest attribute. Especially in stand 1, but also in stand 2, most of the aspens had smaller $d b h$ values, less than 25 $\mathrm{cm}$ (Table 1, Figure 3) and correspondingly the RMSE\% figures are high. On the other hand, the RMSE\% figures are lower in stand 3 where the diameter distribution (Figure 3C.) shows that a remarkable proportion of aspens that reside in the group of trees is in the $d b h$-class larger than $25 \mathrm{~cm}$. Finally, in general the results are most accurate for $D_{g} M$.

In the case of PPS sampling, the chosen auxiliary information metric from ALS was $h_{\text {mean }}^{2}$, which is based on the correlation estimate (0.76) between aspen $V$ and this ALS metric in 15 sample plots of Koli NP. Corresponding correlations between this ALS metric and grid cell level values in the study area were also calculated, and the effect of the PPS sampling on the reliability of $V$ estimates in general is presented in Table 3. As shown, the correlation was close to zero in stand 2 and the effect of PPS sampling is negative in this case. Regarding the two other stands the correlations between ALS metric and volume were greater than 0.3 , and the improvements in volume estimates were more than $10 \%$ and $3 \%$, respectively. The minor improvement in stand 3 may be related to the existence of very large aspens.

\section{Shape of the diameter distribution estimate}

The shape of the diameter distribution of aspen was unimodal and skewed to the right in stand 2, descending in stand 1 , and bimodal in stand 3 (Figure $3 \mathrm{~A}-\mathrm{C}$ ). The shape of sample plot based diameter distribution estimates obtained from the simulations was examined in stands 1 and 3, including ecologically interesting descending and bimodal distributions, respectively. Examination was implemented by classifying the diameter distribution estimate of each simulation according to the rules presented in the methods. In stand 1 the proportion of fixedradius plot estimates, which correctly classified the descending structure, ranged from $50 \%-80 \%$ for $5-20$ plots (Table 4). This was the case both for systematically and randomly located plots. For stand 3 with a bimodal structure, the proportion of correctly classified plots with different number of sample plots corresponded to those of stand 1 , but the success rates were lower. 
Table 2 Relative RMSE and bias (in brackets) values of the forest attributes in three study stands

\begin{tabular}{|c|c|c|c|c|c|c|c|}
\hline \multirow[t]{2}{*}{ Stand } & \multirow[t]{2}{*}{ Sampling rate (\%) } & \multirow[t]{2}{*}{ Sampling alternative } & \multirow[t]{2}{*}{ Number of plots } & \multicolumn{4}{|c|}{ RMSE (\%) (bias \%) } \\
\hline & & & & $v$ & $N$ & $D_{g} M$ & $N_{d b h>25 \mathrm{~cm}}$ \\
\hline \multirow[t]{8}{*}{1} & 2.48 & Random & 5 & $62.0(-3.4)$ & $64.3(-5.0)$ & $56.9(-10.6)$ & $81.8(-2.4)$ \\
\hline & 4.97 & Random & 10 & $43.8(-3.3)$ & $45.6(-2.9)$ & $35.2(-6.0)$ & $58.2(-3.5)$ \\
\hline & 7.45 & Random & 15 & $35.2(0.6)$ & $36.2(0.2)$ & $23.5(-3.6)$ & $47.7(-0.5)$ \\
\hline & 9.94 & Random & 20 & $30.5(-1.4)$ & $31.0(-1.2)$ & $15.5(-2.1))$ & $41.8(-2.1)$ \\
\hline & & Systematic & 5 & $50.8(-3.0)$ & $56.0(-4.4)$ & $48.2(-6.8)$ & $74.3(-1.2)$ \\
\hline & & Systematic & 10 & $34.5(-0.1)$ & $40.1(-1.4)$ & $35.8(-6.1)$ & $48.5(0.1)$ \\
\hline & & Systematic & 15 & $25.9(-2.3)$ & $21.5(-1.5)$ & $17.8(-1.8)$ & $49.7(-4.2)$ \\
\hline & & Systematic & 20 & $24.5(-1.8)$ & $25.5(-1.2)$ & $13.5(-2.5)$ & $38.5(-2.8)$ \\
\hline \multirow[t]{8}{*}{2} & 3.36 & Random & 5 & $85.7(-0.2)$ & $83.8(0)$ & $29.4(1.3)$ & $87.1(-0.8)$ \\
\hline & 6.72 & Random & 10 & $59.8(1.2)$ & $59.7(0.6)$ & $24.5(-1.4)$ & $60.6(0.2)$ \\
\hline & 10.08 & Random & 15 & $50.0(-0.2)$ & $49.2(0)$ & $21.1(-1.3)$ & $50.1(-0.2)$ \\
\hline & 13.45 & Random & 20 & $41.8(0.7)$ & $42.7(-0.6)$ & $18.7(-0.4)$ & $42.8(-0.1)$ \\
\hline & & Systematic & 5 & $84.4(-3.8)$ & $98.2(-8.2)$ & $28.6(0.9)$ & $91.9(-5.9)$ \\
\hline & & Systematic & 10 & $53.2(0)$ & $47.6(-2.4)$ & $23.6(-0.6)$ & $52.2(-1.4)$ \\
\hline & & Systematic & 15 & $37.6(1.4)$ & $38.3(-0.5)$ & $18.5(-0.3)$ & $42.2(0.5)$ \\
\hline & & Systematic & 20 & $30.6(0.1)$ & $31.1(-0.6)$ & $16.9(-0.2)$ & $34.6(-0.3)$ \\
\hline \multirow[t]{8}{*}{3} & 1.55 & Random & 5 & $51.1(0.2)$ & $64.5(-0.5)$ & $21.0(0.5)$ & $52.8(-0.1)$ \\
\hline & 3.09 & Random & 10 & $36.0(-0.2)$ & $46.3(-1.8)$ & $13.1(0.5)$ & $37.7(-0.7)$ \\
\hline & 4.64 & Random & 15 & $29.0(-0.5)$ & $37.3(-1.0)$ & $10.1(-0.1)$ & $30.1(-0.5)$ \\
\hline & 6.18 & Random & 20 & $25.2(0.1)$ & $31.7(-0.8)$ & $8.5(0.1)$ & $25.6(0.2)$ \\
\hline & & Systematic & 5 & $53.6(-1.2)$ & $58.4(2.9)$ & $18.5(0.5)$ & $52.9(-0.5)$ \\
\hline & & Systematic & 10 & $33.6(-0.4)$ & $35.5(-0.7)$ & $12.8(-1.6)$ & $36.4(-0.6)$ \\
\hline & & Systematic & 15 & $26.7(0)$ & $29.8(-0.7)$ & $7.7(-0.2)$ & $24.2(0)$ \\
\hline & & Systematic & 20 & $33.8(0.1)$ & $35.7(0.4)$ & $7.2(-0.5)$ & $31.9(-0.2)$ \\
\hline
\end{tabular}

\section{Spatial pattern of trees}

The analysis based on mapped aspen data with Ripleys K-function showed that in all three stands the aspens are clustered, because the expected value of other trees close to each tree is larger than a Poisson distribution would suggest (Figure 4A-C). Correspondingly, the analysis based on sampling simulations and Fisher's index showed that in each case the average value showed that spatial pattern was clustered (Table 5). Also the proportion of simulations showing clustered spatial pattern was always over $50 \%$, even with just five sample plots.

Table 3 Correlation and the improvement in the RMSE of $V(\%)$ due to the use of ALS auxiliary information in PPS sampling

\begin{tabular}{llll}
\hline Statistical variable & \multicolumn{3}{l}{ Stand } \\
\cline { 2 - 4 } & $\mathbf{1}$ & $\mathbf{2}$ & $\mathbf{3}$ \\
\hline Correlation & 0.35 & 0.04 & 0.33 \\
Improvement in the RMSE of $V(\%)$ & 10.6 & -7.0 & 3.2 \\
\hline
\end{tabular}

\section{Discussion}

This study considered stand level aspen populations in a boreal nature reserve. The analysis was based on diameter distribution, spatial pattern of aspen trees and reliability figures of forest attribute estimates of stand level inventory. Our unique data included mapped aspen trees

Table 4 Proportion (\%) of correctly classified diameter distribution types in $\mathbf{2 5 0 0}$ simulations

\begin{tabular}{llll}
\hline Stand & Number of plots & \multicolumn{2}{c}{ Inventory method } \\
\cline { 3 - 4 } & & Systematic & Random \\
\hline 1 & 5 & 51.2 & 54.9 \\
& 10 & 65.4 & 66.9 \\
& 15 & 76.0 & 75.0 \\
& 20 & 78.8 & 78.6 \\
3 & 5 & 35.3 & 36.7 \\
& 10 & 52.2 & 49.9 \\
& 15 & 55.2 & 54.7 \\
& 20 & 65.1 & 61.7 \\
\hline
\end{tabular}



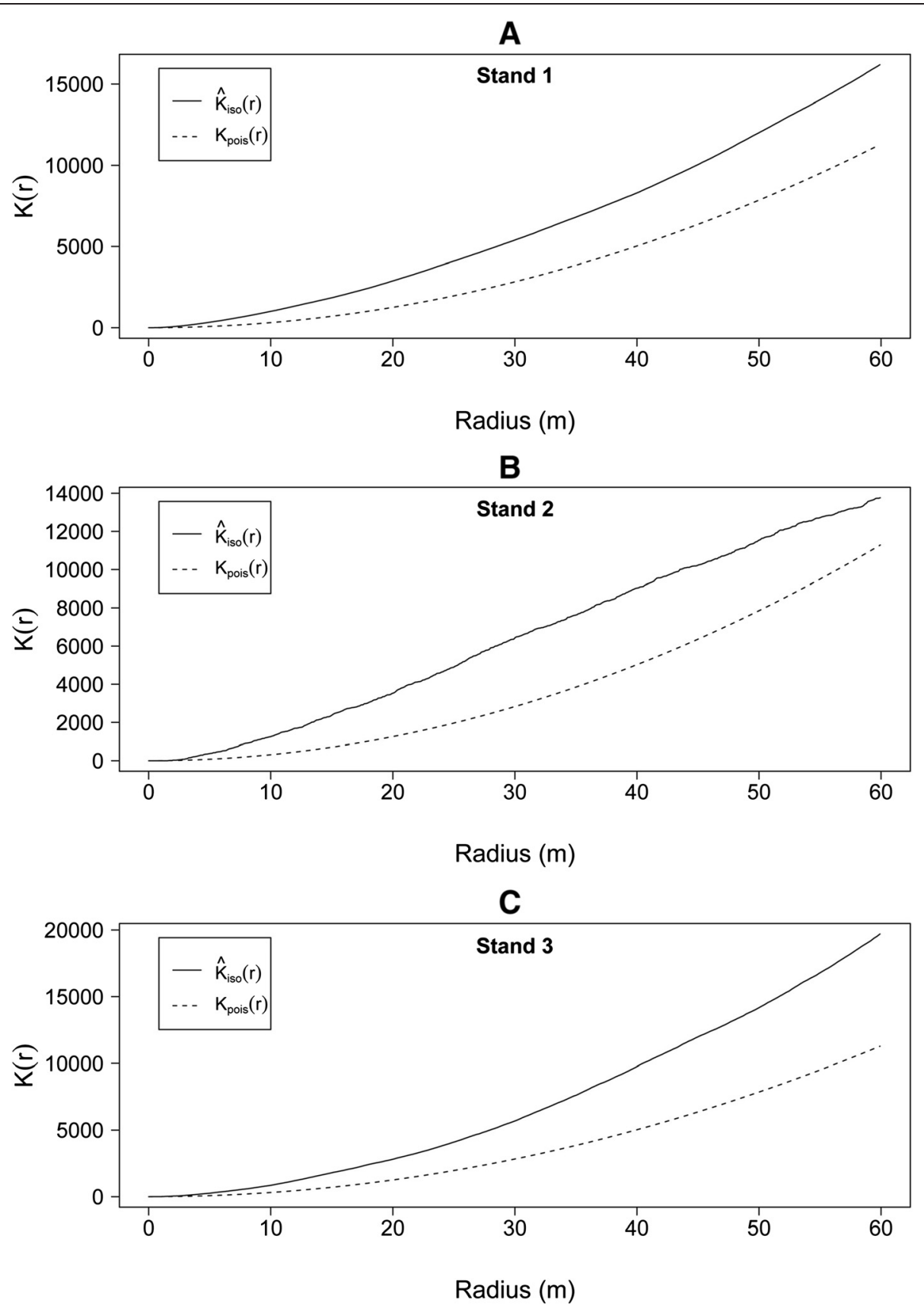

Figure 4 Ripley's K function for stands 1-3 ( $\mathbf{A}=$ stand 1, $\mathbf{B}=$ stand 2, C =stand 3). The dashed line describes the expected value of trees based on Poisson distribution with radius $r$, and solid line the estimate obtained using Ripley's $\mathrm{K}$ function and isotropic edge correction.

in three spruce dominated forest stands where local aspen populations have survived during the past 100 years (Vehmas et al. 2009b). These stands also represent favourable growing environments of aspen. The proportion of aspen in these stands is considerably higher than the average value of $1.5 \%$ in Finland (Tomppo et al. 2001) being $16.3 \%, 5.5 \%$ and $16.2 \%$ of basal area in stands 1,2 and 3, respectively. These statistics are for the forest area in general, but in conservation areas the proportion of aspen is usually considerably larger. It also should be noted that our study stands were rather large in size compared to the average stand size, which is ca. 2 ha in southern Finland. However, with respect to the state-owned forests and conservation areas where aspen is common, the stand sizes used in this study were broadly similar.

The acceptable level of forest attribute results is, of course, dependent on the need for information, but according to inventory by compartments, the RMSE 
Table 5 Average values of Fisher index and proportion of clustered spatial patterns of aspen trees in $\mathbf{2 5 0 0}$ simulations

\begin{tabular}{|c|c|c|c|c|c|}
\hline \multirow[t]{2}{*}{ Stand } & \multirow{2}{*}{$\begin{array}{l}\text { Number } \\
\text { of plots }\end{array}$} & \multicolumn{2}{|l|}{ Random } & \multicolumn{2}{|c|}{ Systematic } \\
\hline & & Average & $\begin{array}{l}\text { Proportion } \\
\text { of clustered } \\
\text { samples }\end{array}$ & Average & $\begin{array}{l}\text { Proportion } \\
\text { of clustered } \\
\text { samples }\end{array}$ \\
\hline \multirow[t]{4}{*}{1} & 5 & 8.6 & 94.1 & 9.5 & 96.1 \\
\hline & 10 & 9.9 & 99.6 & 10.0 & 99.2 \\
\hline & 15 & 10.0 & 100.0 & 11.4 & 100.0 \\
\hline & 20 & 10.6 & 100.0 & 10.6 & 100.0 \\
\hline \multirow[t]{4}{*}{2} & 5 & 1.9 & 56.1 & 2.0 & 60.4 \\
\hline & 10 & 2.3 & 73.4 & 2.6 & 84.1 \\
\hline & 15 & 2.6 & 84.5 & 2.7 & 90.9 \\
\hline & 20 & 2.7 & 90.2 & 2.8 & 95.6 \\
\hline \multirow[t]{4}{*}{3} & 5 & 3.0 & 94.1 & 3.1 & 96.1 \\
\hline & 10 & 3.5 & 95.6 & 3.7 & 89.8 \\
\hline & 15 & 3.7 & 95.6 & 4.1 & 98.7 \\
\hline & 20 & 3.9 & 98.0 & 4.0 & 97.0 \\
\hline
\end{tabular}

values of $V$ for deciduous tree species in mixed stands should be between $20 \%-50 \%$ in Finnish conditions (Uuttera et al. 2002). However, in the previous studies the RMSE\% figures have been higher (65\%) for deciduous tree species (birches) (Haara and Korhonen 2004). Our results showed, in general, that with the lower number of sample plots the RMSE figures are over $50 \%$ but the requirement set by Uuttera et al. (2002) is possible to obtain by measuring 10 or more plots. Between the three stands, the differences in accuracy were caused by the amount of aspen growing stocks, the sizes of the stands (i.e., sampling intensity) and small differences in the spatial patterns of trees. The effect of these aspects is to some extent inversely related. For example, in stand 2 , the sampling intensity was highest, but also the RMSE figures were still the highest. This is most likely due to the low amount of aspen in the growing stock.

We also guided random sample plot placement by applying auxiliary ALS information with PPS sampling. This kind of approach previously has been applied in studies by Pesonen et al. (2010a, b) in the estimation of quantities of coarse woody debris (CWD). The chosen ALS metric, the square of the mean height of laser echoes emphasized the grid cells with the tallest trees. In our case, this technique decreased sampling efficiency in stand 2. This was due to the negative correlation between aspen volume and the square of the mean height of laser, i.e. the tallest trees in stand 2 are not aspens. This can be considered a drawback of the approach. If pre-information concerning the chosen variable does not hold true, the benefit is completely lost. In our case, the correlation between aspen volume and ALS metric-derived mean height was very strong in the 15 large sized fixedarea aspen sample plots, which were earlier used in single tree-based aspen detection from ALS data in the same Koli area (Säynäjoki et al. 2008), but obviously this kind of information cannot be generalised without risks associated with the extrapolation.

With respect to aspen populations in conservation areas, the detailed information on diameter distribution (e.g., the number of large aspens and the shape of distribution) is also of primary interest because many aspenassociated species are highly specialised to specific tree properties (Kouki et al. 2004; Sahlin and Ranius 2009). While descending diameter distribution shapes are interpreted as indicators of uneven-aged stand structure and, thus, may reflect the continuity of aspen populations, bimodal distributions reveal the existence of more than one aspen layer, which is usually also strongly related to the stand age structure. Information on both of these distribution types can be utilised in the management of conservation areas, and without this information, the management lacks primary attributes characterising stands. Regarding our results on mimicking distribution types with 10 fixed-radius plots, the proportions of correctly described diameter distributions were about $65 \%$ and $50 \%$ when obtained for the descending and bimodal diameter distributions, respectively. These proportions can be further increased more than 10 percentage units by increasing the number of sample plots. The same trend is also true for $N_{d b h>25 \mathrm{~cm}}, 10$ or more measured sample plots may be required to reach the $25 \%-50 \%$ level of RMSE\%.

During the last fifteen years, numerous field-based sampling methods for assessing different sparse populations have been presented (e.g. Holopainen et al. 2006; Ringvall et al. 2007; Gove et al. 2013). Although aspen populations are sparse in general this is not the case in our study data. The abundance of aspen in our stands is comparable to the abundance of birch in Finland which constitutes $17 \%$ of growing stock and is the third most frequent tree species of the country (Metsätilastollinen vuosikirja 2013). In such conditions the use of sparse population inventory methods may lead to high cost and time-consuming fieldwork. Since there are numerous sampling methods for sparse populations, the suitability of some of these, such as parallel strips suggested by Marquardt et al. (2012), could be investigated for our data that is, in any case, a topic for future studies.

According to the analysis of spatial patterns, the aspens were strongly clustered in all three stands. This is in line with previous findings (e.g. Syrjänen et al. 1994). In general clustered spatial patterns of trees make inventory more challenging (Pippuri et al. 2012) which is consistent with the RMSE\% levels of our study. On the other hand, it is worth noting that the clustered spatial pattern of aspens was also successfully identified from sample 
plots without the information of tree location. This is an important outcome for planning aspen inventories.

In our study, remote sensing was only applied as auxiliary information in PPS sampling. However, in earlier studies, individual aspens have been detected from ALS data or they have been part of tree stock descriptions in area-based approaches. The problems related to singletree detection include the typically very low general detection rate and overlapping of aspen intensity values with other tree species, such as birch and pine. Also, the vast size of the crown of mature aspen trees would eventually cause difficulties for interpretation when crown sizes of other trees were considerably smaller. On the other hand, when successful, single-tree detection would reveal unforeseen information on aspen crowns. Here, we did not apply single-tree detection, since the technique was already tested with data from Koli NP by Säynäjoki et al. (2008). In the case of ABA, earlier studies have shown poor accuracy estimates obtained for aspen. In our case, this approach was inapplicable, since the number of measured training plots available in Koli NP was not adequate and the forest vertical structure and tree species constitution outside Koli NP is considerably different.

\section{Conclusions}

This study characterized European aspen populations for the purposes of monitoring and management of boreal conservation areas. Our results suggest that if the number of sample plots is adequate, i.e. 10 or more using plot size $400 \mathrm{~m}^{2}$, stand level inventory will provide accurate enough forest attributes estimates in conservation areas (minimum accuracy requirement of RMSE\% is $20 \%-50 \%)$. Even for the more ecologically valuable attributes, such as diameter distribution, spatial pattern and large aspens, the estimates are acceptable for conservation purposes. Between the three stands, the differences in accuracy were caused by the amount of aspen growing stocks, the sizes of the stands and small differences in the spatial patterns of trees. ALS-based auxiliary information might also be useful in guiding the inventory. However, there is still the major risk that relying on ALS may decrease accuracy. Completely remote sensing-based inventory applications for such detailed attributes obtainable for aspens must still await further development of sensors and algorithms, such as multispectral ALS or combination of ALS and hyper spectral data.

\section{Competing interests}

The authors declare that they have no competing interests.

\section{Authors' contributions}

MM participated to all phases of the study. AP calculated the results concerning sampling simulations and participated to writing of corresponding parts of the study. LK calculated the results concerning spatial pattern of trees and participated to writing of corresponding parts of the study. JK was responsible of the ecological part of the Background and
Discussion. MV conducted fieldwork and ALS metrics analysis. KE participated planning and writing of the study. All authors have read and commented the manuscript. All authors read and approved the final manuscript.

\section{Acknowledgements}

This work was supported by by the strategic funding of the University of Eastern Finland. We thank Ms Anne Nylander for her help with the compilation of the figures.

\section{Author details}

${ }^{1}$ University of Eastern Finland, School of Forest Science, P.O. Box 111, Fl-80101 Joensuu, Finland. 'Blom Kartta Oy, Kauppakatu 15, 80100 Joensuu, Finland. ${ }^{3}$ City of Joensuu, 80100 Joensuu, Finland. ${ }^{4}$ Natural Resources Institute Finland, Joensuu Unit, P.O. Box 68, FI-80101 Joensuu, Finland.

Received: 15 December 2014 Accepted: 17 April 2015

Published online: 01 May 2015

\section{References}

Axelsson P (2000) DEM generation from laser scanner data using TIN models. In: The International Archives of the Photogrammetry and Remote Sensing, vol 33, Part B4/1, Amsterdam, pp 110 - 117

Baddeley A, Turner R (2005) Spatstat: an R package for analyzing spatial point patterns. J Stat Soft 12:1-42

Beers TW (1966) The direct correction for boundary-line slopover in horizontal point sampling. Research Progress Report 224, Purdue University, Agricultural Experiment Station, Lafayette, Indiana, p 8

Breidenbach J, Næsset E, Lien V, Gobakken T, Solberg S (2010) Prediction of species-specific forest inventory attributes using a nonparametric semi-individual tree crown approach based on fused airborne laser scanning and multispectral data. Remote Sens Environ 114:911-924

Esseen PA, Ehnström B, Ericson L, Sjöberg K (1992) Boreal forests-the focal habitats of Scandinavia. In: Hansson L (ed) Ecological Principles of Nature Conservation. Elsevier Applied Science, London

Gove JH, Ducey MJ, Valentine HT, Williams MS (2013) A comprehensive comparison of perpendicular distance sampling methods for sampling downed coarse woody debris. Forestry 86:129-143

Grönlund A, Hakalisto S (1998) Management of traditional rural landscapes in Koli National Park. Separate plan of Koli National Park. North Karelia Regional Environment Centre, Joensuu, Regional environmental publications 104, pp 81

Haara A, Korhonen KT (2004) Kuvioittaisen arvioinnin luotettavuus. Metsätieteen aikakauskirja 4(2004):489-508

Heliövaara K, Väisänen R (1984) Effects of modern forestry on northwestern European forest invertebrates: a synthesis. Acta For Fenn 189:1-32

Holopainen M, Leino O, Kämäri H, Talvitie M (2006) Drought damage in the park forests of the city of Helsinki. Urban For Urban Gree 4:75-83

Kalliola R (1973) Suomen kasvimaantiede. Werner Söderström Osakeyhtiö, Porvoo

Kärkkäinen S (1994) Herb-rich forest vegetation of the Koli area. Publication of the Water and Environment Administration: series A 172, pp 51

Kinnunen J, Maltamo M, Päivinen R (2007) Standing-volume estimates of forests in Russia: how accurate is the published data? Forestry 80:53-64

Koivuniemi J, Korhonen KT (2006) Inventory by compartments. In: Kangas A., Maltamo M. (eds) Forest Inventory. Methodology and Applications. Managing Forest Ecosystems, vol 10, Springer, Dordrecht, pp 271-278

Korpela I, Ørka H-O, Maltamo M, Tokola T, Hyyppä J (2010) Tree species classification in airborne LiDAR data: influence of stand and tree factors, intensity normalisation, and sensor type. Silva Fenn 44:319-339

Kouki J, Arnold K, Martikainen P (2004) Long-term persistence of aspen, a key host for many threatened species, is endangered in old-growth conservation areas in Finland. J Nat Conserv 12:41-52

Kurkela T (1973) Epiphytology of Melampsora rusts of Scots pine (Pinus sylvestris L.) and aspen Populus tremula L. The Finnish Forest Research Institute Research Report 79, pp 68

Laasasenaho J (1982) Taper curve and volume functions for pine, spruce, and birch. Commun Inst For Fenn 108:74

Lilja S, Wallenius T, Kuuluvainen T (2006) Structural characteristics and dynamics of old Picea abies forests in northern boreal Fennoscandia. EcoScience 13:181-192

Lyytikäinen A (1991) Kolin luonto, maisema ja kulttuurihistoria. Kolin luonnonsuojelututkimukset. Vesi- ja ympäristöhallituksen monistesarja 308 
Maltamo M, Packalen P (2014) Species-specific management inventory in Finland. In: Maltamo M, Naesset E, Vauhkonen J (eds) Forestry Applications of Airborne Laser Scanning: Concepts and Case Studies. Managing Forest Ecosystems, vol. 27th edn. Springer, Dordrecht, pp 241-252

Marquardt T, Temesgen H, Eskelson BNI, Anderson P (2012) Evaluation of sampling methods to quantify abundance of hardwoods and snags within conifer dominated riparian zones. Ann For Sci 69:821-828

Metsätilastollinen vuosikirja (2013) http://www.metla.fi/julkaisut/metsatilas tollinenvsk. Accessed 20 Dec 2013

Næsset E (2004) Practical large-scale forest stand inventory using a small-footprint airborne scanning laser. Scand J For Res 19:164-179

Næsset E (2007) Airborne laser scanning as a method in operational forest inventory: status of accuracy assessments accomplished in Scandinavia. Scand J For Res 22:433-442

Ørka HO, Næsset E, Bollandsås OM (2007) Utilising airborne laser intensity for tree species classification. In: International Archives of the Photogrammetry, Remote Sensing, and Spatial Information Sciences, vol 36, Part 3/W52, pp 300-304

Packalén P, Maltamo M (2007) The k-MSN method in the prediction of species-specific stand attributes using airborne laser scanning and aerial photographs. Remote Sens Environ 109:328-341

Pesonen A, Kangas A, Maltamo M, Packalén P (2010a) Different sources of auxiliary information in coarse woody debris inventory. Forest Ecol Manag 259:1890-1899

Pesonen A, Maltamo M, Kangas A (2010b) The comparison of airborne laser scanning-based probability layers as auxiliary information for assessing coarse woody debris. Int J Remote Sens 31:1245-1259

Pippuri I, Kotamaa E, Maltamo M, Peltola H, Packalén P (2012) Exploring horizontal area-based metrics to discriminate the spatial pattern of trees and need for first thinning using airborne laser scanning. Forestry 85:305-314

Pippuri I, Maltamo M, Packalen P, Mäkitalo J (2013) Predicting species-specific basal areas in urban forests using airborne laser scanning data and existing stand register data. Eur J For Res 132:999-1012

Poso S (1983) Basic features of forest inventory by compartments. Silva Fenn 17:313-349

Ringvall A, Snäll T, Ekström M, Ståhl G (2007) Unrestricted guided transect sampling for surveying sparse species. Can J For Res 37:2575-2586

Ripley BD (1981) Spatial statistics. John Wiley \& Sons, New York

Ripley BD (1988) Statistical inference for spatial processes. Cambridge University Press, Cambridge

Sahlin E, Ranius T (2009) Habitat availability in forests and clearcuts for saproxylic beetles associated with aspen. Biodivers Conserv 18:621-638

Säynäjoki R, Packalén P, Maltamo M, Vehmas M, Eerikäinen K (2008) Detection of aspens using high-resolution aerial laser scanning data and digital aerial images. Sensors 8:5038-5055

Schreuder HT, Gregoire TG, Wood GB (1993) Sampling Methods for Multiresource Forest Inventory. John Wiley \& Sons, New York

Stokland JN, Holien H, Gaarder G (2002) Arealtall for boreal regnskog i Norge 2002. NIJOS-rapport 2:1-20

Syrjänen K, Kalliola R, Puolasmaa A, Mattson J (1994) Landscape structure and forest dynamics in sub-continental Russian European taiga. Ann Zoo Fenn 31:19-34

Tikka PS (1954) Structure and quality of aspen stands. I. Structure. Commun Inst For Fenn 44:1-33

Tomppo E, Henttonen H, Tuomainen T (2001) Valtakunnan metsien 8. inventoinnin menetelmä ja tulokset Metsäkeskuksittain Pohjois-Suomessa 1992-94 sekä tulokset Etelä-Suomessa 1986-92 ja koko maassa 1986-94. Metsätieteen aikakauskirja B/2001: 99-248

Uuttera J, Hiltunen J, Rissanen P, Anttila P, Hyvönen P (2002) Uudet kuvioittaisen arvioinnin menetelmät- Arvio soveltuvuudesta yksityismaiden metsäsuunnittelu. Metsätieteen Aikakauskirja 3(2002):523-531

Vehmas M, Eerikäinen K, Peuhkurinen J, Packalén P, Maltamo M (2009a) Airborne laser scanning-based identification of herb-rich mature forests in the Koli National Park, eastern Finland. Forest Ecol Manag 257:46-53

Vehmas M, Kouki J, Eerikäinen K (2009b) Long-term spatiotemporal dynamics and historical continuity of European aspen (Populus tremula L.) stands in Koli National Park, eastern Finland. Forestry 82:135-148

\section{Submit your manuscript to a SpringerOpen ${ }^{\odot}$ journal and benefit from:}

- Convenient online submission

- Rigorous peer review

- Immediate publication on acceptance

- Open access: articles freely available online

- High visibility within the field

- Retaining the copyright to your article

Submit your next manuscript at $>$ springeropen.com 